\title{
GEOMORPHOLOGY OF THE BRAGANÇA COASTAL ZONE, NORTHEASTERN PARÁ STATE
}

\section{PEDRO WALFIR MARTINS E SOUZA FILHO AND MAÂMAR EL-ROBRINI}

\begin{abstract}
The area can be subdivided into three main geomorphologic compartments: (1) alluvial plain, with fluvial channels, levees and flood plain; (2) estuarine plain, with an estuarine channel subdivided into estuarine funnel segment, straight segment, meandering segment and upstream channel and; (3) coastal plain, with salt marshes (inner and outer), tidal flats (supratidal mangroves, intertidal mangroves and sandy tidalflats), chenier sand ridges, coastal dunes, barrier-beach ridges and ebb-tidal delta environments. The Braganfa coastal zone is an active sedimentary region, which has been developed largely since the higher Holocene sea level (5,100 years BP). It has been concluded, based on geomorphology, lithostratigraphy and sedimentary processes, which the coastal plain has evolved from mangrove progradatipn, protected by dune-beach ridges with associated fluvial-estuarine-tidal channels. Therefore, the sedimentary model shows a complex depositional system, which is influenced by a broad tidal range.
\end{abstract}

Keywords: Coastal geomorphology, macro tidalflat, mangrove, remote sensing, Northern Brazil.

INTRODUCTION Geomorphology is the science concerned with relationship between landforms and the processes currently acting on them (Summerfield 1991). Coastal zone environments are products of many complex interacting processes (transport, erosion and deposition) which continually modify rocks and sediments. According to Summerfield (1991), coastal zones are broad and reach from the landward limit of marine processes to the seaward limit of alluvial and shoreline processes. Therefore, coastal zone is the region between continental and marine environments where occur estuaries, deltas, tidal flats, salt marshes, barrier islands, cheniers, beaches and other coastal landforms.

In the Northeastern part of the State of Pará (Amazon Region) the coastal environments are dominated by macrotidal systems $(6 \mathrm{~m}$ ranges). The dominant geomorphologic features usually consist of wide muddy tidal flats (mangroves) with estuaries, shoals, salt marshes, cheniers, dunes, beaches and associated washover deposits (Silva 1996, Souza Filho and El-Robrini 1996).

The morphology and sedimentary facies of coastal environments are the product of interactions between relative sea levels, coastal processes and sediment supply. Tidal coastal plains develop under conditions of rising sea-level (transgressive coasts) or stable or falling sea-level (prograding coasts) in response to different combinations of sea-level changes history (Dalrymple et al. 1992). These settings are responsible for landward migration of the shoreline (transgression) and seaward migration of the shoreline (regression) and may be identified by geomorphologic mapping. Therefore, the recognition of shoreline deposits may be crucial to understand the sea-level changes and the stratigraphic sequence (Reading and Collinson 1996). The purpose of this study was to investigate the coastal zone geomorphology of Braganga plain to add to the understanding of the coastal evolution.

REGIONAL SETTING The Bragança coastal zone is situated in the northeastern part of the State of Pará, in the Cretaceous BragangaViseu coastal basin (Cretaceous). Distribution and thickness of the Tertiary and Quaternary deposits have been controlled by the geometry of the basin and its paleotopography, and by recent tectonic movements. This coastal plain constitutes a macrotidal $(6 \mathrm{~m})$ depositional system, developed in a hot and humid equatorial climate, with dry and wet well-defined seasons and an annual precipitation averaging 3,000 $\mathrm{mm}$; relative humidity varies from 80 to $91 \%$ (Martorano et al. 1993).

The Brazilian coastline is currently undergoing different tectonic, geomorphic, climatic and oceanographic processes. The Northern Brazilian Region is characterized by a wide continental shelf, the Northeastern Pará coastal zone being represented by an embayed coastline developed over Tertiary deposits, clastic and carbonatic sediments of the Barreiras Group and Pirabas Formation, respectively. These Tertiary deposits constitute the coastal plateaus which are continuous along the Northern Brazilian coast at elevations of about 50 to $60 \mathrm{~m}$, decreasing progressively seaward, where it forms inactive and active cliffs along of shoreline and estuarine margins (Souza Filho and El-Robrini 1996).

The littoral zone from the Amazonas River to the Gurupi River has a width of about $600 \mathrm{~km}$. In this region, Franzinelli (1992) could distinguish two primary geomorphological features on the coastline:
(1) emergence coast, represented by Marajó Island, with a straight coastline, and (2) submergence coast, east of Marajó Bay to Gurupi Bay; the latter was subdivided in two sectors, a first one, from Marajó Bay to Pirabas Bay, where the bays cut active cliffs; and the second, east of Pirabas Bay, where the coastal plateaus extend southward as inactive cliffs (Fig. 1).

METHODS The coastal zone mapping was based on TM Landsat5 imagery dated from 24/July/91, orbit-point 222-61 in digital format. The TM Landsat-5 data were digitally processed. Standard procedures were used, including geometric and radiometric corrections and image enhancement. The interpretation of satellite data in the form of false color Composite (TM4, TM5, TM3) and digitally enhanced products were made using standard key such as tone/color, texture, pattern, form, size, geometry, drainage and others. A detailed analysis of the spectral signatures of terrain associated with important elements both of geometric and textural characteristics of the coastal landforms, made it possible to identify different geomorphologic units.

Fieldwork was carried out to check the features observed in the image interpretation. During geomorphological mapping were identified vegetation, sediment texture and landforms of different coastal units, which were positioned through of global positional system (GPS). Each coastal unit was described and sampled by vibracorer technique and the sediments collected were analyzed.

GEOMORPHOLOGIC CLASSIFICATION OF THE COASTAL ZONE The coastal zone geomorphic classification was based on landforms, sediment patterns, and dominant processes in operation (historical processes); some other factors, including geomorphological processes, land use and land cover, were also considered. Three large geomorphological compartments were mapped: coastal plain, estuarine plain and alluvial plain.

Coastal plain The coastal plain is the most extensive of the three geomorphologic compartments. It extends north of the coastal plateaus for more than $20 \mathrm{~km}$, occurring as wide tidal flats, until it reaches the shoreline dominated by marine processes (Fig. 1). The major landforms observed are tidal mudflats (mangrove), salt marshes, tidal sandflats, chenier sand ridges, coastal sand dunes, barrier-beach ridges and ebb-tidal delta. Important observations in relation to geomorphological processes, sediment patterns, coastal processes, land use and land covers are highlighted below according to geomorphological classification.

TIDAL MUDFLATS (MANGROVE) The tidal mudflats constitute a wide mangrove ecosystem with a width of about $20 \mathrm{~km}$, densely covered by mangrove trees (Fig. 2). They are located between the high spring tide and mean tidal level. Organic muddy sediments are deposited on the tidal flats during the slack tide water, when the currents decrease. Simple lenticular bedding with fine sand lenses, wavy bedding, tidal bundle and massive muddy sediments containing plant fragments and roots occur in the sedimentary mudflat deposits'. Field studies have indicated that Rhizophora sp. And Avicennia sp. are the dominant species commonly found along this coast. The distribution of tidal flats is mainly controlled by topography. 


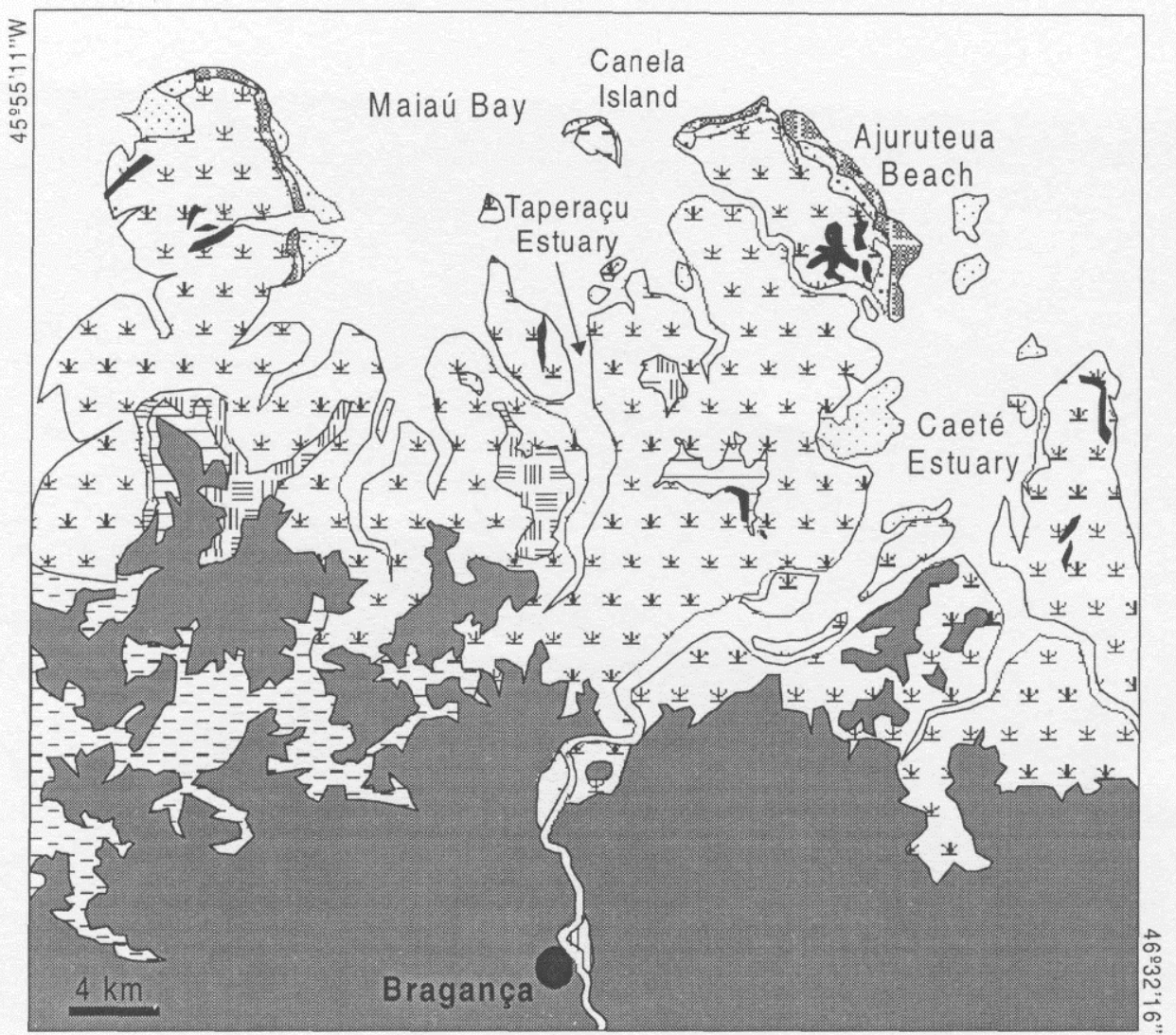

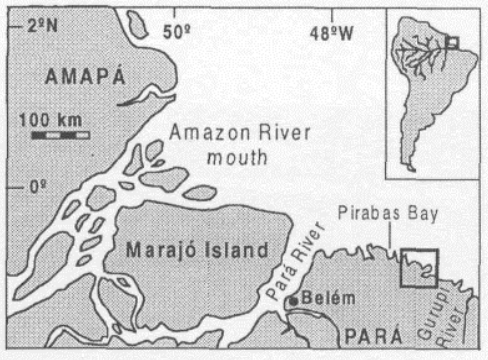

Coastal plateaus

Coastal plain

位 Supratidal mudflats

\section{* Intertidal mudflats}

E- Inner salt marshes

$\nexists$ Outer salt marshes

$\therefore$ Tidal sandflats

Chenier sand ridges

$\because$ Coastal sand dunes

浆䛜 Barrier-beach ridges

\section{Estuarine plain}

Alluvial plain

$01^{\circ} 04^{\prime} 17^{\prime \prime}$

Figure 1 - Map localization of study area and coastal zone geomorphologic map (Modified from Souza Filho and El-Robrini 1998).

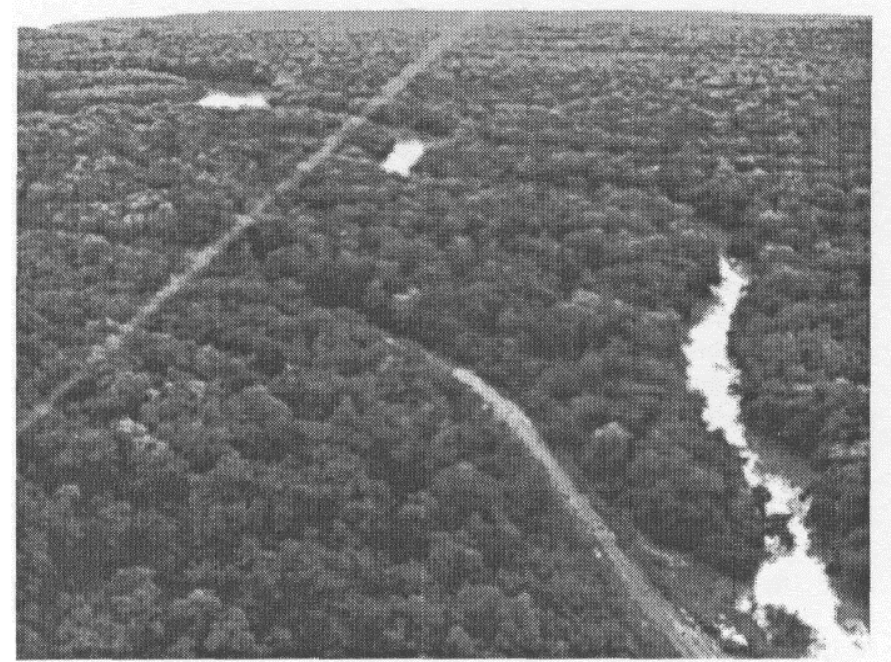

Figure 2 - Tidal mudflat sedimentary environments densely covered by mangrove trees

Therefore, based on relative altimetry and vegetation height, the tidal flats were subdivided in supratidal mangrove and intertidal mangrove The supratidal mangroves are topographically higher with smaller trees and can be reached by water only during the spring tides, while the intertidal mangroves are topographically lower with progradacional and erosional areas.

SALT MARSHES The salt marshes are known in the area as "Campos de Bragança". The marshes are situated in the supratidal zone; sedimentation is marked by mud deposition carried from tidal fluxes along creeks (Souza Filho and El-Robrini 1996). They are subdivided

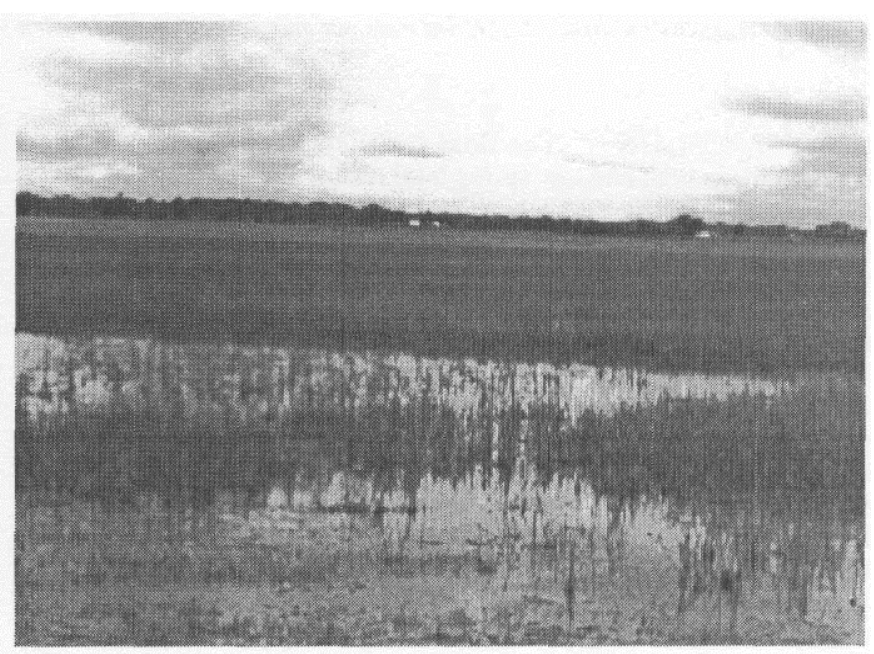

Figure 3 - Inner salt marshes flooded during the rainy season.

in inner and outer salt marshes. The inner salt marsh occurs over the coastal plateaus and is flooded only during the rainy season and tidal waters influence its tidal creeks only during the dry season (Fig. 3). The outer salt marsh occurs over old sandy beach ridge deposits along the tidal mudflat (Fig. 4). Outer salt marshes are frequently flooded during the spring tides. The map in Figure 1 shows the spatial relationship between salt marsh, old beach ridges (cheniers) and tidal mudflats.

This unit is constituted by massive mud, but it is possible observe fine sand lenses intercalated by mud that characterize a simple lenticular bedding (Souza Filho and El-Robrini 1998). 


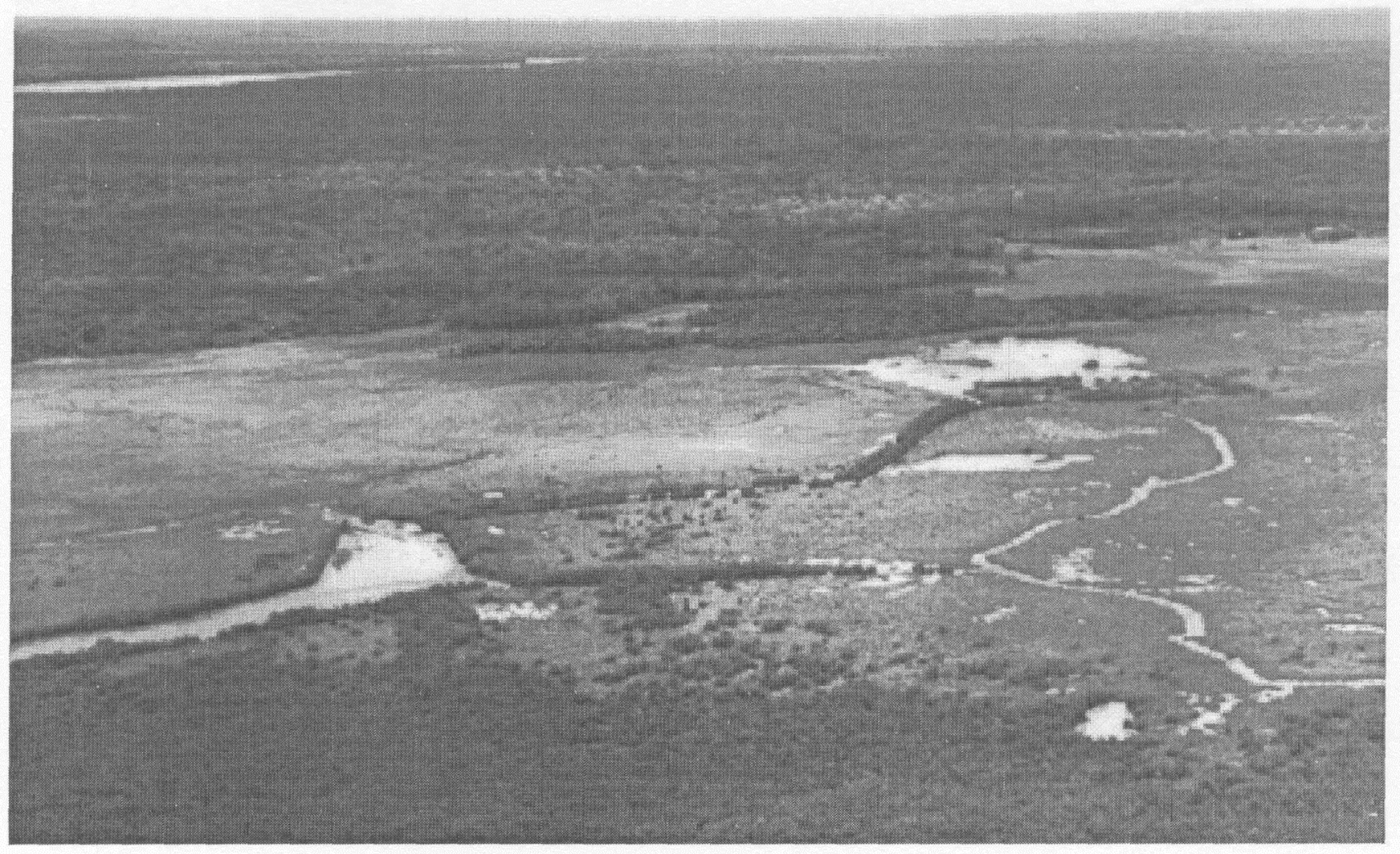

Figure 4 - Outer salt marshes developed over old barrier-beach ridges (sandy ridge covered by trees).

TIDAL SANDFLATS The tidal sandflats occur along the coast between mean tidal and low spring tidal levels. This unit is represented by sandy tidal shoals, which have many ripples, and megaripple marks and sand waves exposed at low tide (Fig. 5). These tidal sandy deposits are characterized by plane-Parállel and tangential cross stratification and simple flaser bedding with burrows filled by mud. Muddy balls reworked by tidal currents also occur along the sandflat.

CHENIER SAND RIDGES The chenier sand ridges constitute old dune-beach ridges with associated washover fans. They are constituted by white fine sand covered by sparse vegetation. The cheniers have a very well characterized geometric linear and curved form whose boundary is marked by prograding tidal mudflats (Fig. 5). The sedimentary processes responsible for its development are related to shoreline retreat during transgressive sea-level conditions followed by mud progradation. The mud progradation sometimes covered the sandy deposits, which allowed mangrove and salt marsh development. Foreset stratification and bioturbed structures deposited over intertidal muddy deposits characterize these coastal landforms.

COASTAL SAND DUNES Sandy sediments of tidal shoals and beach reworked by the wind constitute the coastal sand dunes. Nowadays, the dunes are migrating landward over the mangrove deposits in the intertidal mudflats. Transverse and pyramidal dunes are partially or completely covered with vegetation and represent coastal dunes composed of very fine quartz sand, which is very well sorted, with few shell fragments and root marks. The transverse dunes present tabular cross stratification and the pyramidal dunes have beds dipping in opposite directions from the ridge which is Parállel to the trade winds direction (Souza Filho and El-Robrini 1996).

BARRIER- BEACH RIDGES The barrier- beach ridges are the most dynamic coastal environments. They extend from low spring tidal levels to dune-beach scarps that represent the higher spring tidal level in the intertidal beach. The beaches have a linear and elongated form along an east-west direction, with curved spits in the longshore sediment transport direction (Fig. 5). These barrier-beach ridges form protected backward areas where muddy sediments are deposited during the slack water and so salt grasses and mangrove trees are installed.

The barrier-beach ridges are dominated by macrotidal conditions and they were subdivided in supratidal zone (backshore), intertidal zone and subtidal zone based on relative tidal level (Wright et al. 1982). The supratidal zone extends above the high spring tide level that coincides with the topographic boundary (dune-beach scarp). The intertidal zone occurs between high and low spring tide level. This zone is subdivided in three sub-zones based on morphologic and sedimentologic characteristics, flooding time and dynamic regimes. The high intertidal zone extends from high spring tide to high neap tide level; the mean intertidal zone is centered between high neap tide and low neap tide level, while the low intertidal zone extends from low neap tide to low spring tide level. The lower area, named subtidal zone, occurs under low spring tide level and extends to the breaker zone.

EBB-TIDAL DELTA The size and shape of ebb deltas are directly related to the relative influence of waves and tidal currents on barrierbeach ridges (Davis Jr. 1992). Where the tidal energy is dominant, ebb deltas extend seaward in the form of large deltas; shore normal sand bodies (Fig. 5). The ebb delta morphology has shallow ebb channels exposed during low spring tide, flanked by sandy bars. These ebb deltas contain a very complex system of bed forms such as different types of ripples, megaripples and sand waves on intertidal sandy bodies. The sediments are very fine to fine, well sorted, with shells and micaceous mineral fragments.

Estuarine plain The estuarine plain extends upstream to the southward, as far as the tidal limit of the Caete and Taperaçu rivers (Fig. 1), to the north its boundary is dominated by marine processes. 


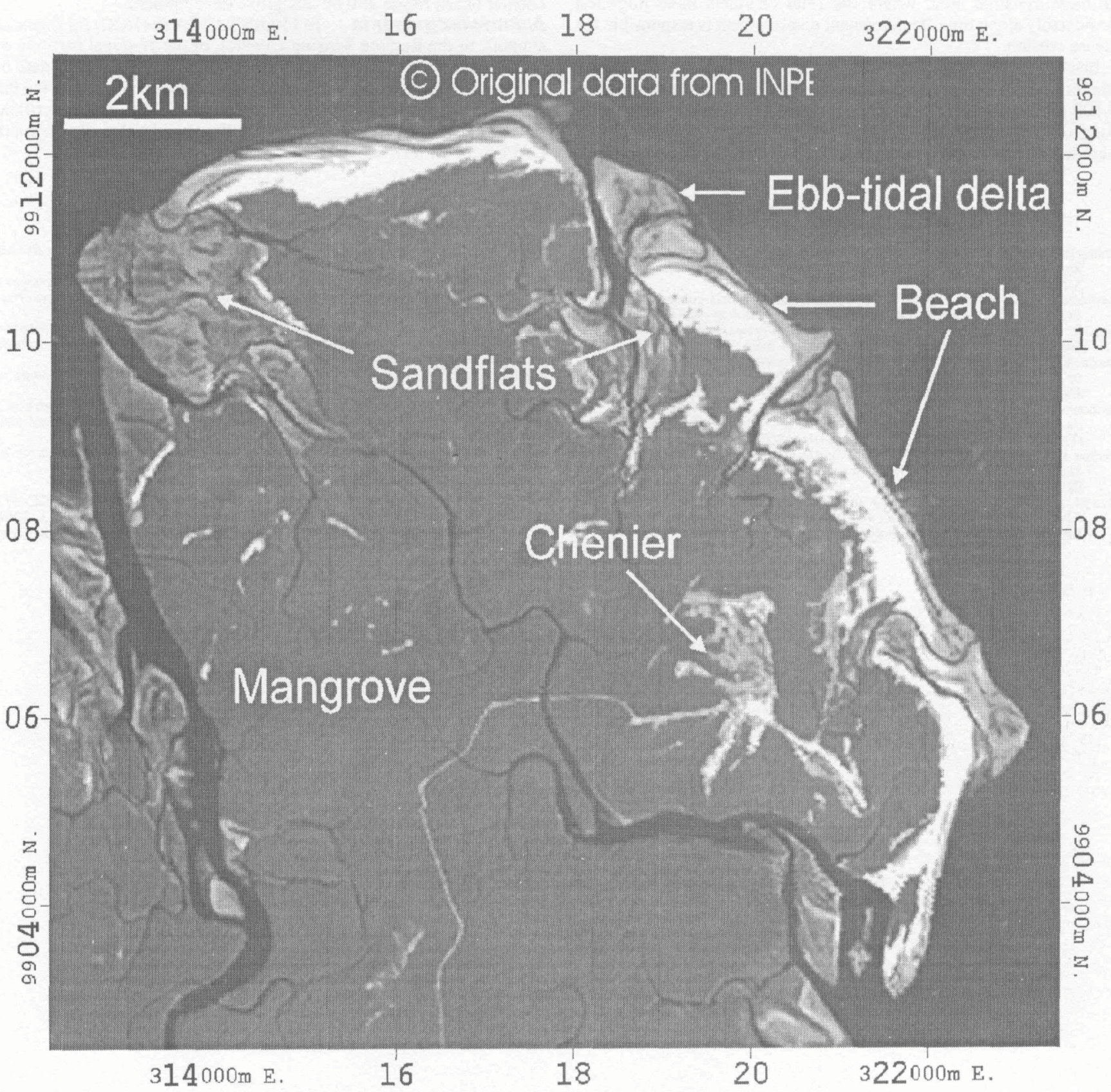

Figure 5 - Band 5 of TM Landsat imagery showing geomorphologic features in the Ajuruteua Island, Braganca coastal plain.

Fluvial, tidal and marine processes influence the river channel. Souza Filho and El-Robrini (1996) observed that geomorphology of the estuarine plain changes between downstream and upstream limits. According to Woodroffe et al. (1989), this is a reflex of progressive change of the river and its wet season flood profile. Souza Filho and El-Robrini (1996) recognized four estuarine channel types in the Caete River: estuarine funnel, straight segment, meandering segment and upstream tidal channel.

Alluvial plain The alluvial plain extends south of the tidal limit, forming the floodplain of the freshwater parts of the Caeté and Taperaçu rivers. The fluvial channels are meandering with longitudinal and point bars, and box morphologic anomalies. The floodplain is bounded by levees and it is flooded during the wet season.

SUMMARY AND CONCLUSIONS TM Landsat imagery and fieldwork have been used for the study of the coastal zone geomorphology of the Braganca plain. Geomorphologically, the investigated area was subdivided into three major compartments: 1) coastal plain, 2) estuarine plain and 3) alluvial plain.

The tidal mudflats have been deposited under progradacional conditions since 5,100 years BP, when mangrove replaced a coastal forest ecosystem (Behling et al. 1999). Inner salt marshes are related to incised-valley fill, while outer salt marshes have its evolution associated to mangrove evolution (Souza Filho and El-Robrini 1998). Tidal sandflats represent one of the most dynamic intertidal zones where tidal currents are responsible for transport, deposition and erosion. Chenier sand ridges mark old beach ridges in the coastal zone showing the great displacement of the shoreline seaward during the Holocene period. Coastal sand dunes are partially or completely covered with vegetation, an evidence of the presence, in the recent past, of a period of dune formation with intense reworking of the sands by wind. However, nowadays, the dunes have been dissipated and waves and tidal currents have eroded dunes along the coast. The beach ridges have been developed under macrotidal conditions and work as barriers, which reduce coastal erosion. These barriers are responsible for the development of protected areas where occurs mud progradation with an increase of the mangrove area. The ebb-tidal delta represents 
the most dynamic area, where the tidal channels have migrated considerably along time. This constant displacement is responsible for intense erosion.

Inactive cliffs bound the coastal plateaus representing older shoreline position developed during the last Holocene transgression $(5,100$ years BP). Simões (1981) obtained this age through dating along the coastal plateaus. Afterwards, the shorelines have been submitted to extensive progradation well defined by the position of chenier beach ridges and by mangrove development. Acknowledgements To PROINT-UFPA (061/CG) for financial support, to the Remote Sensing Division of the National Institute of Spatial Research (DSR-INPE) for providing original digital data of TM Landsat imagery, to Carlos Alberto Albuquerque for reviewing the English and to two anonymous reviewers of RBG for the critical review of the manuscript. The first author would also like to thank CAPES for a Ph.D. scholarship.

\section{References}

Behling H., Cohen M. C. L, Lara R, J. 1999. Holocene mangrove dynamics of the Braganca Region on Northeastern Pará, Brazil. In: Madam Project, International Conference, 5. Belem, Abstracts, 10-11.

Dalrymple R. W., Zaitlin B. A., Boyd R. 1992. Estuary facies models: conceptual basis and stratigraphic Implications. Journal of Sedimentary Petrology, 62:1130-1146.

Davis Jr. R. A. 1992. Depositional system: An Introduction to Sedimentology and Stratigraphy. $2^{\text {nd }}$ ed., New Jersey, Prentice Hall, 604p.

Franzinelli E. 1992. Evolution of the geomorphology of the coast of the State of Pará, Brazil. In: M. T. PROST (ed.) Evolution des littoraux de Guyane et de la Zone Caraibe Meridionale pendant le Quaternaire. Paris, ORSTOM, 203-230.

Martorano L. G., Perreira L. C., G§zar E. G. M., Pereira I. C. B. 1993. Estudos Climaticos do Estado do Pará, Classificacao Climdtica (K6PPEN) e Deficiencia Hidrica (THORNTHWHITE, MATHER). Belem, SUDANI/EMBRAPA, 53p

Reading H. G. and Collinson J. D. 1996. Clastic coasts. In: H.G. READING (ed.) Sedimentary Environments: Processes, Facies and Stratigraphy. $3^{\text {rd }}$ ed. Oxford, Sedimentary Environments: Proc
Blackwell Science, $154-231 \mathrm{p}$.

Silva M. S. 1996. Morfoestratigrafia e evolução holocenica da Planicie Costeira de Salinopolis, Nordeste do Estado do Pará. Centre de Geociências, Universidade Federal do Pará. Belein, Disserta9ao de Mestrado, 142p.
Simões M. F. 1981. Coletores - Pescadores ceramistas do litoral do salgado (Pará). Boletim do Museu Paráense Emilio Goeldi, Nova Serie Antropologia, 78:1-33.

Souza Filho P. W. M. and El-Robrini M. 1996. Morfologia, processes de sedimentação e litofácies dos ambientes morfosedimentares da Planfcie Costeira Bragantina - Nordeste do Pará (Brasil). Geonomos, 4:1-16.

Souza Filho P. W. M. and El-Robrini M. 1998. As variações do nível do mar e a estratigrafia de sequencias da Planície Costeira Bragantina - Nordeste do Pará, Brasil. Boletim do Museu Paráense Emilio Goeldi, Serie Ciências da Terra, 10:45-78.

Summerfield M. A. 1991. Global geomorphology: an introduction to the study of landforms. New York, Longman, $537 \mathrm{p}$.

Woodroffe C. D., Chappell J., Thorn B.C., Wallensky E. 1989. Depositional models of a macrotidal estuary and flood plain, South Alligator River, Northern Australia. Sedimentology, 36:737-756.

Wright L. D., Nielsen P., Short A. D., Green M. 0.1982. Morphodynamics of a macrotidal beach. Marine Geology, 50:97-128.

Contribution IGC-177
Received March 3,2000 Accepted for publication April 28, 2000 